\title{
Discordance to ASHP Therapeutic Guidelines Increases the Risk of Surgical Site Infection
}

\author{
Fauna Herawati ${ }^{1,2, *(D)}$, Rika Yulia ${ }^{1}$, Heru Wiyono ${ }^{3}$, Firdaus Kabiru Massey ${ }^{1}$, Nurlina Muliani ${ }^{1}$, \\ Kevin Kantono ${ }^{4}{ }^{(}$, Diantha Soemantri ${ }^{5}{ }^{(-)}$and Retnosari Andrajati ${ }^{2}$ \\ 1 Department of Clinical and Community Pharmacy, Faculty of Pharmacy, Universitas Surabaya, \\ Surabaya 60293, Indonesia; rika_y@staff.ubaya.ac.id (R.Y.); firdaus.kabiru@gmail.com (F.K.M.); \\ nurlinamuliani95@gmail.com (N.M.) \\ 2 Department of Pharmacology and Clinical Pharmacy, Faculty of Pharmacy, Universitas Indonesia, \\ Depok 16424, Indonesia; retnosaria@gmail.com \\ 3 Faculty of Medicine, Universitas Surabaya, Surabaya 60293, Indonesia; herwyno@yahoo.com \\ 4 Department of Food Science, Auckland University of Technology, Private Bag 92006, \\ Auckland 1142, New Zealand; kevin.kantono@aut.ac.nz \\ 5 Department of Medical Education, Faculty of Medicine, Universitas Indonesia, Depok 16424, Indonesia; \\ diantha.soemantri@ui.ac.id \\ * Correspondence: fauna@staff.ubaya.ac.id
}

Citation: Herawati, F.; Yulia, R.;

Wiyono, H.; Massey, F.K.; Muliani, N.;

Kantono, K.; Soemantri, D.; Andrajati,

R. Discordance to ASHP Therapeutic

Guidelines Increases the Risk of

Surgical Site Infection.

Pharmaceuticals 2021, 14, 1088.

https://doi.org/10.3390/ph14111088

Academic Editor: Marco Fiore

Received: 16 September 2021

Accepted: 22 October 2021

Published: 27 October 2021

Publisher's Note: MDPI stays neutral with regard to jurisdictional claims in published maps and institutional affiliations.

Copyright: (C) 2021 by the authors Licensee MDPI, Basel, Switzerland. This article is an open access article distributed under the terms and conditions of the Creative Commons Attribution (CC BY) license (https:/ / creativecommons.org/licenses/by/ $4.0 /)$.

\begin{abstract}
Clean surgery without contamination does not require prophylactic antibiotics, but there are high-risk surgical procedures that may cause infection and/or involve vital organs such as the heart, brain, and lungs, and these indeed require the use of antibiotics. This study aimed to determine the quantity of antibiotic use based on the defined daily dose (DDD) per 100 bed days and the quality of antibiotic use based on the percentage of concordance with The American Society of Health-System Pharmacists (ASHP) therapeutic guidelines (i.e., route of administration, time of administration, selection, dose, and duration). This includes the profiles of surgical site infection (SSI) in surgical patients from January through June 2019. The study subjects were 487 surgical patients from two hospitals who met the inclusion criteria. There were 322 patients out of 487 patients who had a clean surgical procedure. Ceftriaxone (J01DD04) was the most used antibiotic, with a total DDD/100 bed days value in hospitals A and B, respectively: pre-surgery: 14.71, 77.65, during surgery: $22.57,87.31$, and postsurgery: $38.34,93.65$. In addition, $35 \%$ of antibiotics were given more than $120 \mathrm{~min}$ before incision. The lowest concordance to ASHP therapeutic guideline in hospital A (17.6\%) and B (1.9\%) was antibiotic selection. Two patients experienced SSI with bacterial growths of Proteus spp., Staphylococcus aureus, Staphylococcus epidermidis, and Escherichia coli. The usage of prophylactic antibiotics for surgical procedures was high and varied between hospitals. Hospital B had significantly lower concordance to antibiotic therapeutic guidelines, resulting to a higher infection rate, compared with hospital A. ASHP adherence components were then further investigated, after which antibiotic dosing interval and injection time was found to be a significant predictor for positive bacterial growth based on logit-logistic regression. Further interventions and strategies to implement antibiotic stewardship is needed to improve antibiotic prescriptions and their use.
\end{abstract}

Keywords: defined daily dose; surgical site infection; antibiotic stewardship; hospital

\section{Introduction}

Antimicrobial resistance threatens global health; antibiotic use in surgical specialties is an infection control indicator and may reflect the incidence of surgical site infection. In most developing countries, particularly Indonesia, antibiotics are given before the incision but also during the time from admission to discharge from the hospital which may result in higher chances of antimicrobial resistance. A new strategy is therefore needed to overcome this problem. 
Surgery is a medical procedure in the form of an incision made by a surgeon with the aim of preventing or treating an illness. In general, all surgical procedures can pose a risk of infection. Thus, antibiotic prophylaxis is needed to prevent postoperative infection. However, not all types of surgery require antibiotic prophylaxis. Clean surgery without contamination does not require prophylactic antibiotics unless there are high-risk procedures that may cause infection and/or involve vital organs such as the heart, brain, and lungs. Prophylactic antibiotics are generally recommended in some clean and all contaminated operations [1]. In general, the use of antibiotic prophylaxis must be in accordance with therapeutic standards. However, the percentage compliance with guidelines for antibiotic use (e.g., NICE Guidelines, Stanford Health Care Guidelines, Surgical Antimicrobial Prophylaxis Guidelines) is relatively low (under 50\%) in several countries such as Qatar $(46.5 \%)$, Pakistan $(<50 \%)$, Italy $(40 \%)$, and the Philippines (13\%) [2].

The mismatch of antibiotic use with therapeutic guidelines is reported to be high in surgical ward [3], ICU [3,4], and medical ward [3] with mismatches to the indication, antibiotic selection [3,4], and time/dose/route/duration of antibiotic administration. Often, differences existed from the internal guidelines [3] especially in prescribing prophylactic antibiotics pre- and postsurgery. A study showed that in pre-surgery, $46 \%$ incorrect timing, $32 \%$ incorrect dosages, and $20 \%$ overly broad antibiotic spectrum were reported; while in postsurgery, they found $74 \%$ incorrect duration of antibiotic administration, $29 \%$ incorrect dosage or frequency, and 6\% overly broad spectrum of antibiotics [5].

Prescribing antibiotics preoperatively can reduce the occurrence of wound infection. Whereas not following the guidelines, for example, by using different spectrum antibiotics or different tissue antibiotic concentrations at the start and during surgery, can reduce antibiotics' effectiveness. Moreover, antibiotic selection pressure leads to antibiotic resistance. The incidence of SSI is significantly higher when prophylactic antibiotics are given postsurgery than when given presurgery with an odds ratio (OR) of 1.89 (95\% CI 1.05-3.4). Prophylactic antibiotics more than $120 \mathrm{~min}$ preincision showed a higher prevalence of SSI than those within $120 \mathrm{~min}$ (OR 5.26; 95\% CI (3.29-8.39)) [6-8]. The use of prophylactic antibiotics that are irrational or not in accordance with therapeutic guidelines requires preventive efforts so as not to cause cases of resistance to prophylactic antibiotics. According to the Indonesian National Action Plan for Antimicrobial Resistance 2017-2019, one of the preventive efforts that can be conducted is to evaluate the use of prophylactic antibiotics in its quantity and quality.

World Health Organization (2019) states that implementing antimicrobial stewardship by evaluating the use of antibiotics can optimize the use of antibiotics, encourage behavior change in prescribing antibiotics, improve quality of care and patient outcomes, save unnecessary health care costs, and reduce the emergence, selection, and further spread of antimicrobial resistance (AMR) [9-14]. A systematic review by Nathwani et al. (2019) of 146 studies in North America (49\%), Europe (25\%), Asia (14\%), Africa (3\%), South America $(3 \%)$, and Australia (3\%) reported a decrease in length of stay (LOS) and antibiotic expenditure, respectively, by 85 and 92\%; mean cost savings in the US study were USD 732 per patient (range: USD 2.50 to 2640), with a similar trend shown in European studies [14]. Hence, taking into account the importance and positive outcome of antibiotics stewardship, this study aimed to evaluate the quantity (DDD/100 bed-days) and quality of prophylactic antibiotic use in surgical patients in hospitals while assessing the impact of concordance towards ASHP therapeutic guideline towards the risk of SSI.

\section{Results}

A total of 487 patients in both hospitals met the inclusion and exclusion criteria. Table 1 describes the demographic information of the patients in the study. Table 1 shows that 268 patients (55\%) were female, 298 patients $(61 \%)$ were aged between 31 and 60 years old, 393 patients $(81 \%)$ of patients with out-of-pocket payment, and 57 patients $(12 \%)$ had comorbidities. Overall, 322 patients underwent surgery with a clean operation category 
(94 patients in hospital A, and 228 patients in hospital B) (Table 1); in 164 patients (34\%), the injection time given was greater than $120 \mathrm{~min}$ (Table 2).

Table 1. Demographics information.

\begin{tabular}{|c|c|c|c|}
\hline Characteristic & Hospital A $(\mathrm{N}=164)$ & Hospital B $(\mathrm{N}=323)$ & Total $(\mathrm{N}=487)$ \\
\hline \multicolumn{4}{|c|}{ Age (years) } \\
\hline $18-30$ & $30(18.3 \%)$ & $59(18.3 \%)$ & $89(18.3 \%)$ \\
\hline $31-45$ & $56(34.1 \%)$ & $95(29.4 \%)$ & $151(31.0 \%)$ \\
\hline $46-60$ & $44(26.8 \%)$ & $103(31.9 \%)$ & $147(30.2 \%)$ \\
\hline $61-75$ & $31(18.9 \%)$ & $66(20.4 \%)$ & $97(19.9 \%)$ \\
\hline$>75$ & $3(1.8 \%)$ & 0 & $3(0.6 \%)$ \\
\hline \multicolumn{4}{|c|}{ Gender } \\
\hline Male & $61(37.2 \%)$ & $158(48.9 \%)$ & $219(45.0 \%)$ \\
\hline Female & $103(62.8 \%)$ & $165(51.1 \%)$ & $268(55.0 \%)$ \\
\hline \multicolumn{4}{|c|}{ Pay providers } \\
\hline Out of pocket & $85(51.8 \%)$ & $308(95.4 \%)$ & $393(80.7 \%)$ \\
\hline $\begin{array}{l}\text { National Health } \\
\text { Insurance }\end{array}$ & $79(48.2 \%)$ & $15(4.6 \%)$ & $94(19.3 \%)$ \\
\hline \multicolumn{4}{|c|}{ Comorbidities } \\
\hline Without comorbidities & $117(71.3 \%)$ & $313(96.9 \%)$ & $430(88.3 \%)$ \\
\hline With comorbidities * & $47(28.7 \%)$ & $10(3.1 \%)$ & $57(11.7 \%)$ \\
\hline \multicolumn{4}{|c|}{ Surgical procedure } \\
\hline Clean & $94(57.3 \%)$ & $228(70.6 \%)$ & $322(66.1 \%)$ \\
\hline Clean contaminated & $65(39.6 \%)$ & $95(29.4 \%)$ & $160(32.9 \%)$ \\
\hline Contaminated $* *$ & $5(3.0 \%)$ & 0 & $5(1.0 \%)$ \\
\hline
\end{tabular}

* Comorbidities: diabetes mellitus (DM), hypertension, cardiovascular disease (CVD), gout, cerebrovascular accident (CVA), and others. ${ }^{* *}$ contaminated: an acute incision, nonpurulent drainage.

\subsection{Quantity Profile of Prophylactic Antibiotics}

Pre-, During, and Postsurgeries

Based on the recapitulation of antibiotic prophylaxis (DDD/100 bed-days) in hospitals A and B, respectively, between January and June 2019, the antibiotic use prophylaxis presurgery was 44.26 and 133.58; during surgery was 33.32 and 132.4; postsurgery was 66.65 and 148.68 . Ceftriaxone had the highest DDD/100 patient days in the pre-, during, and postsurgery, with sequences of 14.71 and 77.65, 22.57 and 87.31, 38.34, and 93.65 (Table 3). Overall, hospital B had significantly higher usage then hospital $\mathrm{A}\left(\mathrm{F}_{(1,5)}=66.124, p<0.001\right)$.

Table 2. Antibiotic usage for both hospitals.

\begin{tabular}{cccc}
\hline Category & Hospital A (N = 164) & Hospital B (N = 323) & Total (N = 487) \\
\hline No antibiotic & The number item of antibiotic & $15(3.1 \%)$ \\
1 antibiotic & $15(9.1 \%)$ & 0 & $453(93.0 \%)$ \\
2 antibiotics & $130(79.3 \%)$ & $323(100 \%)$ & $18(3.7 \%)$ \\
$>2$ antibiotics & $18(11.0 \%)$ & 0 & $1(0.2 \%)$ \\
\hline & $1(0.6 \%)$ & 0 & $92(18.9 \%)$ \\
0-30 min & Injection time given & $115(23.6 \%)$ \\
$61-60$ min & $35(21.3 \%)$ & $57(17.6 \%)$ & $101(20.7 \%)$ \\
$>120$ min & $32(19.5 \%)$ & $83(25.7 \%)$ & $164(33.7 \%)$ \\
Record not available & $55(33.5 \%)$ & $46(14.2 \%)$ & $15(3.1 \%)$ \\
\hline
\end{tabular}


Table 3. The DDD per 100 bed-days antibiotics use for surgical procedures.

\begin{tabular}{|c|c|c|c|c|c|c|c|}
\hline \multirow{2}{*}{ ATC $^{*}$ Code } & \multirow{2}{*}{ Antibiotic Name } & \multicolumn{2}{|c|}{ Pre- } & \multicolumn{2}{|c|}{ During } & \multicolumn{2}{|c|}{ Post- } \\
\hline & & Hospital A & Hospital B & Hospital A & Hospital B & Hospital A & Hospital B \\
\hline J01CA04 & Amoxicillin & - & 7.93 & - & - & 0.72 & 1.11 \\
\hline J01CR01 & Bactesyn $^{a}$ & - & - & - & 5.59 & - & - \\
\hline J01CR02 & Clanexi ${ }^{b}$ & - & - & - & - & - & 0.54 \\
\hline J01DB04 & Cefazolin & 0.74 & - & 2.82 & - & 1.55 & - \\
\hline J01DB05 & Cefadroxil & - & 0.94 & - & - & - & 1.09 \\
\hline J01DD01 & Cefotaxime & - & 6.07 & 0.04 & 8.92 & 0.04 & 8.70 \\
\hline J01DD02 & Ceftazidime & - & 2.87 & 0.14 & 3.96 & - & 3.72 \\
\hline J01DD04 & Ceftriaxone & 14.71 & 77.65 & 22.57 & 87.31 & 38.34 & 93.65 \\
\hline J01DD08 & Cefixime & - & 18.70 & - & - & - & 26.79 \\
\hline J01DD62 & $\begin{array}{l}\text { Cefoperazone } \\
\text { Sulbactam }\end{array}$ & 12.26 & 0.67 & 3.06 & 0.62 & 10.17 & 0.79 \\
\hline J01DE01 & Cefepime & 1.47 & - & 0.14 & - & 1.45 & - \\
\hline J01DH02 & Meropenem & 14.34 & - & 1.59 & - & 4.94 & - \\
\hline J01FF01 & Clindamycin & - & - & - & - & - & 1.65 \\
\hline J01GB03 & Gentamicin & - & - & - & - & 0.17 & - \\
\hline J01MA02 & Ciprofloxacin & - & - & - & - & - & 1.97 \\
\hline J01MA12 & Levofloxacin & - & 16.07 & 0.14 & - & 0.64 & - \\
\hline J01MA14 & Moxifloxacin & - & - & - & 23.51 & - & 3.03 \\
\hline J01XA01 & Vancomycin & - & 2.68 & - & 1.60 & - & 3.41 \\
\hline J01XD01 & Metronidazole & 0.74 & - & 2.82 & 0.89 & 8.63 & 2.23 \\
\hline Total & & 44.26 & 133.58 & 33.32 & 132.40 & 66.65 & 148.68 \\
\hline
\end{tabular}

* Anatomical therapeutic chemical; ${ }^{\mathrm{a}}$ _ampicillin and beta-lactamase inhibitor; ${ }^{\mathrm{b}}$-amoxicillin and beta-lactamase inhibitor.

\subsection{Quality Profiles of Prophylactic Antibiotics}

Other than the route of administration, compatibility with ASHP guidelines was less than $50 \%$. Order from highest to lowest conformity, the concordance to the ASHP guidelines was route of administration, injection given time, dosage, dosing interval, and selection (Table 4). In general, hospital A was more compliant than hospital B. Logistic regression revealed that injection given time $\left(\mathrm{X}^{2}{ }_{(1,162)}=283.62 ; p<0.001\right)$ and dosing interval $\left(\mathrm{X}^{2}{ }_{(1,162)}=4.165 ; p<0.041\right)$ were significant predictors for infection cases in hospital $\mathrm{B}$.

\subsection{Profile of Surgical Site Infection (SSI)}

Surgical site infection occurs related to surgical incision procedures within 90 days of follow-up. Only two patients experienced SSI in this study. Both patients experiencing postoperative SSI were identified after undergoing a third review in the first patient, and after the first review in the second patient. The results of the first patient's pus culture showed the presence of Proteus spp. and S. aureus, while the second patient had E. coli and S. epidermidis. Profiles of the types of bacteria that cause SSI are shown in Table 5. Both SSI patients were known to have had a history of diabetes mellitus, with a random blood sugar level of $<200 \mathrm{mg} / \mathrm{dL}$ while in the hospital, LOS preoperatively for $>1$ day, undergoing surgery with a duration of operation $>60 \mathrm{~min}$. The first SSI patient did not receive presurgical antibiotics, while the second patient received $2 \times 1 \mathrm{~g}$ of ceftriaxone preoperative antibiotics for 1 day. Both SSI patients received the same prophylactic antibiotic, i.e., ceftriaxone $2 \times 1 \mathrm{~g}$ with the administration time $>120 \mathrm{~min}$, and both dosages were continued until 4-5 days after incision. Neither received antibiotics when they were discharged.

Table 4. The percentage concordance to ASHP Therapeutic Guidelines.

\begin{tabular}{cccc}
\hline Concordance Type & Hospital A & Hospital B & z-Test (Monte Carlo) \\
\hline Antibiotic route of administration & 96.6 & 100.0 & $\mathrm{z}=-0.034 ; p<0.05$ \\
Antibiotic injection given time & 53.4 & 42.7 & $\mathrm{z}=2.211 ; p<0.05$ \\
Antibiotic selection & 17.6 & 1.9 & $\mathrm{z}=4.966 ; p<0.001$ \\
Antibiotic dosage & 16.4 & 46.7 & $\mathrm{z}=-7.445 ; p<0.001$ \\
Antibiotic dosing interval & 19.1 & 19.2 & $\mathrm{z}=0.000 ; p=1.0$ \\
\hline
\end{tabular}


Table 5. The incidence of surgical site infection.

\begin{tabular}{ccc}
\hline Category & Hospital A & Hospital B \\
\hline $\begin{array}{c}\text { Patients who return for control } \\
\text { and culture }\end{array}$ & 0 & 4 \\
$\begin{array}{c}\text { Patients with positive bacteria } \\
\text { culture result }\end{array}$ & 0 & 2 \\
The bacteria culture result & - & $\begin{array}{l}\text { Patient 1: Proteus sp. dan S. aureus } \\
\text { Patient 2: E. coli dan S. epidermidis }\end{array}$ \\
\hline
\end{tabular}

\subsection{Bacteria Sensitivity Profile Causes SSI}

The results of antibiotic sensitivity tests showed that Escherichia coli bacteria are still sensitive to several types of antibiotics, such as cefoxitin, chloramphenicol, fosfomycin, oxacillin, tetracycline, and vancomycin. Bacteria Proteus spp. were sensitive to antibiotics such as amoxicillin, amoxicillin-clavulanate, ampicillin, ciprofloxacin, cotrimoxazole, fosfomycin, norfloxacin, ofloxacin. Proteus spp. and had intermediate sensitivity to cefoxitin and chloramphenicol. Staphylococcus aureus bacteria were sensitive to chloramphenicol, oxacillin, and vancomycin and had intermediate sensitivity to amoxicillin, amoxicillinclavulanate, and cefoxitin.

\section{Discussion}

\subsection{Quantity Profiles of Prophylactic Antibiotics}

The assessment of the quantity of antibiotic use was conducted by calculating DDD/100 bed-days based on the classification (Anatomical Therapeutic Chemical Classification) that has been approved worldwide by the World Health Organization (WHO). DDD is defined as the use of antibiotics based on the average daily dose given to $70 \mathrm{kgs}$ adult patients according to main therapeutic indications. However, DDD cannot provide information pertaining to the suitability of the actual daily dose prescription. DDD calculation is influenced by the amount of antibiotic use (grams) and the total length of stay (bed-days). The higher percentage of antibiotics use leads to the greater the DDD value [15].

The calculation of DDD/100 bed-days between January and June 2019 was divided into pre-, during, and postsurgeries. Overall, the average of prophylactic antibiotic use in pre, during, and postsurgeries in hospital B was higher than in hospital A. Ceftriaxone is the most widely used antibiotic including surgery. Tolbert's 2019 evaluative study on the use of ceftriaxone in tertiary hospitals in Tanzania showed 322 (51.1\%) of 630 research samples used ceftriaxone antibiotics. A total of 44 samples (40.7\%) received ceftriaxone for surgical prophylaxis purposes that were divided into $32(72.7 \%)$ samples receiving antibiotics before surgery, 3 samples (6.8\%) samples receiving ceftriaxone antibiotics during surgery, and 9 samples (20.5\%) receiving antibiotics after surgery [16]. Another evaluative study on the use of prophylactic antibiotics in surgical patients at Nekemte Hospital Ethiopia showed that the 153 ceftriaxone samples were the most widely used antibiotics, with a total of 66 samples (43.1\%) [17].

Prophylactic antibiotics can significantly reduce the risk of postoperative infections. A meta-analysis of 40 studies testing the effectiveness of ceftriaxone compared with the comparators as the surgical prophylaxis (ampicillin-sulbactam, benzylpenicillin, cefamandole, cefazolin, cefotaxime, cefuroxime) showed that in clean operations, the incidence of SSI in ceftriaxone was $5.14 \%$, and comparator $6.2 \%$ (OR $-0.22,95 \%$ CI -0.51 to 0.01 ; $p=0.047)$. In clean-contaminated operations, the incidence of SSI in ceftriaxone was $4.6 \%$ and comparator $6.4 \%$ (OR $-0.36,95 \% \mathrm{CI}-0.67$ to $-0.13 ; p=0.001)$ [18].

The average value of DDD/100 prophylactic antibiotic bed-days in this study is higher than other studies in one hospital in Indonesia but is still lower than that in the study of the use of prophylactic antibiotics in one hospital in Turkey. The ceftriaxone antibiotics dosage used in hospital B was 87 DDD/100 bed-days, which means there were 87 out of 100 patients who received ceftriaxone 1 DDD antibiotics per day. A primary study of surgical patients in the hospitals in Surabaya assessed the total use of ceftriaxone 
prophylactic antibiotics using the DDD/100 bed-days unit, and the total use of these antibiotics was 30-54 DDD/100 bed-days $[19,20]$. These results are still lower when compared with DDD/100 bed-days of this study. However, the total use of prophylactic antibiotics in this study was still lower than that in Turkey, which was 132.4 DDD/100 bed-days, compared with $289.32 \mathrm{DDD} / 100$ bed-days [21].

\subsection{Quality Profiles of Prophylactic Antibiotics}

According to Permenkes RI RI No. 2406/MENKES/PER/XII/2011 on General Guidelines for the Use of Antibiotics in 2011, the basis for selecting antibiotics should be drawn from the patterns of bacterial sensitivity to antibiotics, the clinical condition of patients, the selection priorities of first-line antibiotics or antibiotics with a narrow spectrum, cost, and adjusted according to the hospital diagnosis and therapy (PDT) Guidelines [11]. The results in this study indicated that of the 487 samples analyzed between January and June 2019, the percentage of compliance with ASHP therapeutic guidelines for the selection of antibiotic types was $18 \%$ in hospital A and $2 \%$ in hospital B. We postulate that the low accordance in hospital B may be due to the fact that in Indonesia, antibiotics selection depends on the availability of the drugs rather than guideline recommendation.

Based on ASHP therapeutic guidelines, to ensure adequate plasma and tissue concentration during surgery, it is recommended that the drug to be given intravenously within one hour of an incision. In this study, more than $95 \%$ of patients received prophylactic antibiotics intravenously, but only around $50 \%$ in concordance with the preoperative dosage timing recommendation.

Some antibiotics, such as vancomycin and fluoroquinolones, must be given $120 \mathrm{~min}$ before surgery due to the influence of the half-life and protein binding of each antibiotic [22,23]. Allegranzi [7] conducted a meta-analysis of 13 observational studies on 53,975 adult patients to assess the optimal time of administration of surgical prophylactic antibiotics and found that preoperative antibiotics are better than postsurgical drugs to prevent surgical site infection (SSI) (OR 1.89; 95\% CI 1.05-3.4). Administration of antibiotics earlier than 120 min showed a higher prevalence of SSI than the administration of antibiotics within $120 \mathrm{~min}$ (OR 5.26; 95\% CI 3.29-8.39).

The incidence of SSI in surgery patients in hospital B from January through June 2019 was 2 out of 323 patients $(0.62 \%)$. The SSI patients in this study both had ceftriaxone at intervals and doses of $2 \times 1 \mathrm{~g}$. The administration time was more than $2 \mathrm{~h}$ preincision. Mismatched timing of prophylactic antibiotics can cause SSI and the growth of resistant bacteria. Research conducted by Billoro in 2019 to evaluate the use of prophylactic antibiotics in 255 surgical patients in southern Ethiopia, using a prospective cohort study, showed that administration of surgical prophylactic antibiotics earlier than $1 \mathrm{~h}$ before the incision was associated with $20 \%$ of SSI cases, whereas administration within $1 \mathrm{~h}$ had a lower incidence, at $11.4 \%(p=0.012)$. In addition, antibiotic resistance was observed in most types of bacteria in the surgical ward. One of these bacteria, Escherichia coli, was resistant to the antibiotics such as ceftriaxone, chloramphenicol, ciprofloxacin, and gentamicin [24].

The selection of the right drug must be accompanied by an accurate dose determination. ASHP guidelines recommend ceftriaxone $2 \mathrm{~g}$, or $50-75 \mathrm{mg} / \mathrm{kg}$ body weight, for adults $[22,23]$. The average body weight of the study sample was $>40 \mathrm{~kg}$; thus, the administration of $<1 \mathrm{~g}$ of ceftriaxone injection was not in accordance with ASHP guidelines [25].

Aside from the timing of the first dose, the dosing interval and duration must be appropriate to achieve minimum effective plasma and tissue concentrations. ASHP recommends a single dose or that the duration of prophylactic antibiotics be $<24 \mathrm{~h}$ postoperatively [23]. Using the case of more than 1000 beds hospital, Ayele's 2017 evaluative study on the use of ceftriaxone in tertiary hospitals showed that around $70 \%$ use of antibiotic prophylaxis for a duration exceeding 7 days [26]. Limiting the duration of prophylactic antibiotics is crucial because the use of antibiotics with a longer duration has the potential to change the normal bacterial flora in the patient's own body and the normal flora in the hospital environment. A disturbed flora can lead to colonization or antimicrobial resistance [25]. 
The use of prophylactic antibiotics $>24$ h carries the risk of increasing the incidence of acute kidney injury and infection by Clostridium difficile bacteria $[27,28]$.

\subsection{Profile of Surgical Site Infection (SSI)}

Extended preoperative waiting times for hospitalized patients increased the risks of SSI. Preoperative waiting time $>7$ days could increase the risk of SSI 2.48 times greater than preoperative waiting time $<7$ days (ARR $=2.48$ (95\% CI 1.28-4.79); $p=0.007)$ [24]. Both our infected patients underwent surgery after undergoing SSI $>7$ days inpatient care. They also had a duration of operation $>1 \mathrm{~h}$. Billoro (2019) found patients who underwent surgery $>1 \mathrm{~h}$ were at risk of experiencing SSI 2.13 times higher than operations of $<1 \mathrm{~h}$ $(\mathrm{ARR}=2.13(95 \%$ CI 1.18-3.86),$p=0.012)$ [24]. Gachabayov [29] found that the incidence of SSI was significantly higher in diabetic patients with hyperglycemia than nondiabetics ones with hyperglycemia $(\mathrm{ARR}=2.10(1.29-3.42, p=0.002))$. Our SSI patients were known to have a record of concomitant diabetes mellitus with preoperative blood sugar levels of $149 \mathrm{mg} / \mathrm{dL}$ and $138 \mathrm{mg} / \mathrm{dL}$. Patients with blood sugar level that exceeded $100 \mathrm{mg} / \mathrm{dL}$ preincision had shown a 1.7 times greater risk of SSI [30].

The strength of this study is its large number of patients ( $n>400)$ and follow-up. The reported cases of surgical site infection were not when the patient was in the hospital (inpatient) but during 30-60 days after the day of surgery when they returned to the outpatient clinic. The limitation of this study is that severe cases in ICU and those who died were not accounted for, and there were laboratory limitations, and therefore, the bacteria that cause SSI were not identified.

\section{Materials and Methods}

\subsection{Study Design}

A retrospective observational study in both hospitals was conducted by observing patients who underwent surgical procedures during hospitalization at a private hospital in Surabaya (hospital A) and West Nusa Tenggara (hospital B) in the period January-June 2019. Hospital A is a private hospital with 235 beds, whereas hospital B is a government hospital with 411 beds. Both hospitals are referral hospitals. Surgical procedures classifications were (1) clean surgery-surgery performed on an area without preoperative infection and without opening the tract (respiratory, gastrointestinal, urinary, biliary), planned surgery, or primary skin closure with or without the use of closed drains, (2) clean-contaminated operations - operations performed on the ducts (gastrointestinal, biliary, urinary, respiratory, and reproductive except ovaries) or operations without significant contamination, and (3) contaminated surgery - surgery that opened the digestive tract, bile duct, urinary tract, airway to the oropharynx, or reproductive tract except for ovaries with gross spillage [6].

Inclusion criteria included patients aged $>18$ years old who received prophylactic antibiotics, underwent surgery, and hospitalization in the surgical ward, including surgical wound control within $<90$ days postoperatively. The exclusion patient criteria were patients in the intensive care unit (ICU), patients who had an infection before surgery, those discharged "against medical advice" (AMA), and those who died.

Slovin's formula was used to calculate the appropriate sample size (n) from a population using the known population size $(\mathrm{N})$ and the acceptable error value (e). In this study, simple random sampling was used from the population of admitted patients in the study period; $\mathrm{N}=267$ participants, $\mathrm{e}=0.05$; therefore, $\mathrm{n}=160$ participants hospital A; $\mathrm{N}=1597$ participants, $\mathrm{e}=0.05$; therefore, $\mathrm{n}=320$ participants hospital $\mathrm{B}$.

Slovin calculations used Equation (1) as follows:

$$
\mathrm{n}=\frac{\mathrm{N}}{\left(1+\mathrm{N} \times 0.05^{2}\right)}
$$

Antibiotic usage data were obtained from patient medical records and antibiotic use records compiled by pharmaceutical software, which stores all patient data. Data were collected from inpatient medical records, including diagnosis, surgery, length of 
hospitalization, drug name, dose, and the number of antibiotics received. The dataset was anonymized prior to analysis.

In Indonesia, antibiotics can be prescribed to the patient at admission, during patient care, until the patient's discharge, and usually two weeks after discharge (next outpatient consultation). In this study, antibiotic use classifications were pre-, during, and postsurgery. Presurgery represents antibiotics given before the day of surgery; antibiotics during surgery are given on the day of surgery (120 min preincision to $<24 \mathrm{~h}$ after surgery), and antibiotics postsurgery are given $>24 \mathrm{~h}$ after surgery.

The obtained data were evaluated for antibiotic uses quantitatively and qualitatively. The quantitative evaluation used DDD per 100 bed-days, while the qualitative analysis was the percentage of antibiotic concordance to the American Society of Health-System Pharmacists (ASHP) Therapy Guidelines in (1) route of administration, (2) time, (3) type, (4) dosage, and (5) duration.

Data on bacterial culture test results were obtained from clinical pathology laboratories, and prevention and control committees of infection to follow up regarding the bacteria that cause SSI in postsurgical patients. Patients with SSI were observed in the time they were in the hospital, and when they went to the doctor for review, until the patient was declared cured.

\subsection{Statistical Analysis}

All patient data were anonymized prior to analysis. Data analysis was performed descriptively in the form of an analysis of the quantity of prophylactic antibiotic use with the DDD/100 bed-days, which was calculated using the following formula:

$$
\frac{\mathrm{DDD}}{100} \text { bed }- \text { days }=\frac{\text { Total Antibiotics }(\mathrm{g}) \times 100}{\text { DDD WHO }(\mathrm{g}) \times \text { LOS }}
$$

where DDD WHO = defined daily dose determined by WHO; LOS = total length of stay.

The percentage of compliance with guidelines of antibiotic use with the ASHP therapeutic guidelines was analyzed using the 2014 SIGN criteria as a quality analysis, including the sensitivity profile of the bacteria causing SSI.

A generalized ANOVA model was also carried out on the aggregated DDD dataset to identify the overall difference between the two hospitals in this study. Z-test, in conjunction with Monte Carlo simulation, was also used to investigate which hospital was most adhering to ASHP guidelines. In addition, logit-logistic regression was utilized in this study to further investigate which ASHP adherence components that would be the significant predictor for reported infection cases. Participants' demographics (e.g., age, gender), comorbidities, and antibiotic usage were included as covariates in the model.

\section{Conclusions}

The usage of prophylactic antibiotics for surgical procedures was high and varied between hospitals. The low concordance to antibiotic therapeutic guidelines suggested injudicious antibiotic use. Further surveillance is needed to identify the incidence of antibiotic-resistant bacteria in the future. It is highly recommended that surgeons abide by guideline recommendations, using only a single antibiotic dose for clean surgery. Further intervention and strategies in implementing antibiotic stewardship are needed to improve antibiotic prescribing and its use.

Author Contributions: Conceptualization, R.Y. and F.H.; methodology, F.H.; software, H.W. and K.K.; validation, F.H. and R.Y.; formal analysis, F.H., F.K.M., N.M. and K.K.; investigation, F.K.M. and N.M.; resources, R.Y. and H.W.; data curation, F.K.M. and N.M.; writing-original draft preparation, F.H. and R.Y.; writing—review and editing, K.K., D.S. and R.A.; visualization, N.M.; supervision, D.S. and R.A.; project administration, R.Y. and F.H.; funding acquisition, R.Y. All authors have read and agreed to the published version of the manuscript. 
Funding: This study receives funding from the Ministry of Research, Technology, and Higher Education of the Republic of Indonesia No. 015/ST-Lit/LPPM-01/RistekBRIN/Multi/FF/III/2021.

Institutional Review Board Statement: This research received research permission from Husada Utama Hospital Surabaya, Surabaya (hospital A), No.1592/RSHU/Dir./X/2019, and the Regional General Hospital of West Nusa Tenggara Province (hospital B), No. 070/5//03/RSUDP NTB. This study has obtained ethical approval issued by the institutional ethical committee of the University of Surabaya, with the Ethics Agreement No. 109/KE/XI/2019, and the Health Research Ethics Commission of the Regional General Hospital of West Nusa Tenggara Province No. 070.1/13/KEP/2019.

Informed Consent Statement: No informed consent was obtained from all subjects involved in the study.

Data Availability Statement: The authors confirm that the data supporting the findings of this study are available on request.

Acknowledgments: The authors would like to thank the directors and staff of both hospitals for allowing us to conduct research in their hospitals. We would like to thank David Scott, Pharmacy Department, Cardiff University, UK for reviewing, editing, and proofreading the manuscript.

Conflicts of Interest: The authors declared no potential conflict of interest with respect to the research, authorship, and/or publication of this article.

Ethics Statement: All procedures performed in this study involving human participants were in accordance with the ethical standards of the institutional and national research committee and with the 1964 Helsinki Declaration and its later amendments or comparable ethical standards. This research received research permission from Husada Utama Hospital Surabaya (hereafter, hospital A), No.1592/RSHU/Dir./X/2019, and the Regional General Hospital of West Nusa Tenggara Province (hereafter, hospital B), No. 070/5//03/RSUDP NTB. This study obtained ethical approval issued by the institutional ethical committee of the University of Surabaya with the Ethics Agreement No. 109/KE/XI/2019 and the Health Research Ethics Commission of the Regional General Hospital of West Nusa Tenggara Province No. 070.1/13/KEP/2019.

\section{References}

1. Yang, X.; Xiao, X.; Wang, L.; Ao, Y.; Song, Y.; Wang, H.; Wang, H. Application of antimicrobial drugs in perioperative surgical incision. Ann. Clin. Microbiol. Antimicrob. 2018, 17, 2. [CrossRef]

2. Satti, M.Z.; Hamza, M.; Sajid, Z.; Asif, O.; Ahmed, H.; Zaidi, S.M.J.; Irshad, U. Compliance Rate of Surgical Antimicrobial Prophylaxis and its Association with Knowledge of Guidelines Among Surgical Residents in a Tertiary Care Public Hospital of a Developing Country. Cureus 2019, 11, e4776. [CrossRef] [PubMed]

3. Çakmakçi, M. Antibiotic stewardship programmes and the surgeon's role. J. Hosp. Infect. 2015, 89, 264-266. [CrossRef] [PubMed]

4. Hussain, K.; Khan, M.F.; Ambreen, G.; Raza, S.S.; Irfan, S.; Habib, K.; Zafar, H. An antibiotic stewardship program in a surgical ICU of a resource-limited country: Financial impact with improved clinical outcomes. J. Pharm. Policy Pract. 2020, 13, 69. [CrossRef]

5. National Centre for Antimicrobial Stewardship; Australian Commission on Safety and Quality in Health Care. Surgical National Antimicrobial Prescribing Survey: Results of the 2016 Pilot; ACSQHC: Sydney, Australia, 2017.

6. WHO. Global Guidelines for the Prevention of Surgical Site Infection, 2nd ed.; Licence: CC BY-NC-SA 3.0 IGO; World Health Organization: Geneva, Switzerland, 2018. Available online: https://apps.who.int/iris/bitstream/handle/10665/250680/9789241 549882-eng.pdf? sequence $=8$ (accessed on 18 June 2021).

7. Allegranzi, B.; Bischoff, P.; de Jonge, S.; Kubilay, N.Z.; Zayed, B.; Gomes, S.M.; Abbas, M.; Atema, J.J.; Gans, S.; van Rijen, M.; et al. New WHO recommendations on preoperative measures for surgical site infection prevention: An evidence-based global perspective. Lancet Infect. Dis. 2016, 16, e276-e287. [CrossRef]

8. Ling, M.L.; Apisarnthanarak, A.; Abbas, A.; Morikane, K.; Lee, K.Y.; Warrier, A.; Yamada, K. APSIC guidelines for the prevention of surgical site infections. Antimicrob. Resist. Infect. Control 2019, 8, 174. [CrossRef] [PubMed]

9. WHO. Global Antimicrobial Resistance Surveillance System (GLASS) Report: Early Implementation 2017-2018; World Health Organization: Geneva, Switzerland, 2018. Available online: https:/ / www.who.int/docs/default-source/searo/amr/global-antimicrobialresistance-surveillance-system---glass-report-early-implementation-2017-2018.pdf?sfvrsn=7e629fec_6 (accessed on 18 June 2021).

10. Indonesian Ministry of Health (IMOH). National Action Plan on Antimicrobial Resistance Indonesia 2017-2019; Kementerian Kesehatan Republik Indonesia: Jakarta, Indonesia, 2017.

11. Indonesian Ministry of Health (IMOH). Peraturan Menteri Kesehatan Republik Indonesia Nomor 2406/MENKES/PER/XII/2011 Tentang Pedoman Umum Penggunaan Antibiotik; Direktorat Jenderal Bina Kefarmasian dan Alat-Kesehatan Kementerian Kesehatan Republik Indonesia: Jakarta, Indonesia, 2011. Available online: https://drive.google.com/file/d/1Pu31AVV9ZFOmInIWyixNwj5 mzAt_mk $X_{w} /$ view (accessed on 7 January 2021). 
12. Delbridge SIGN 104: Antibiotic Prophylaxis in Surgery. July 2008, Updated April 2014. Available online: http://www.sign.ac.uk/ (accessed on 24 April 2018).

13. World Health Organization. Antimicrobial Stewardship Programmes in Health-Care Facilities in Low-and Middle-Income Countries: A WHO Practical Toolkit; World Health Organization: Geneva, Switzerland, 2019. Available online: https://apps.who.int/iris/ handle/10665/329404 (accessed on 18 June 2021).

14. Nathwani, D.; Varghese, D.; Stephens, J.; Ansari, W.; Martin, S.; Charbonneau, C. Value of hospital antimicrobial stewardship programs [ASPs]: A systematic review. Antimicrob. Resist. Infect. Control 2019, 8, 35. [CrossRef] [PubMed]

15. Indonesian Ministry of Health (IMOH). Peraturan Menteri Kesehatan Republik Indonesia Nomor 8 Tahun 2015 Tentang Program Pengendalian Resistensi Antimikroba di Rumah Sakit; Kementerian Kesehatan Republik Indonesia: Jakarta, Indonesia, 2015. Available online: https:/ /ghsaindonesia.files.wordpress.com/2016/02/peraturan-menteri-kesehatan-ri-no-8-tahun-2015-tentangpengendalian-resistensi-antimikroba-di-rumah-sakit.pdf (accessed on 18 June 2021).

16. Sonda, T.B.; Horumpende, P.G.; Kumburu, H.H.; van Zwetselaar, M.; Mshana, S.E.; Alifrangis, M.; Lund, O.; Aarestrup, F.M.; Chilongola, J.O.; Mmbaga, B.T.; et al. Ceftriaxone use in a tertiary care hospital in Kilimanjaro, Tanzania: A need for a hospital antibiotic stewardship programme. PLoS ONE 2019, 14, e0220261. [CrossRef]

17. Alemkere, G. Antibiotic usage in surgical prophylaxis: A prospective observational study in the surgical ward of Nekemte referral hospital. PLoS ONE 2018, 13, e0203523. [CrossRef] [PubMed]

18. Esposito, S.; Noviello, S.; Vanasia, A.; Venturino, P. Ceftriaxone versus other antibiotics for surgical prophylaxis: A meta-analysis. Clin. Drug Investig. 2004, 24, 29-39. [CrossRef] [PubMed]

19. Pratama, N.Y.I.; Suprapti, B.; Ardhiansyah, A.O.; Shinta, D.W. Analisis penggunaan antibiotik pada pasien rawat inap Bedah dengan menggunakan Defined Daily Dose dan Drug Utilization 90\% di Rumah Sakit Universitas Airlangga. J. Farm. Klin. Indones. 2019, 8, 256-263. [CrossRef]

20. Herawati, F.; Yulia, R.; Hak, E.; Hartono, A.H.; Michiels, T.; Woerdenbag, H.J.; Avanti, C. A retrospective surveillance of the antibiotics prophylactic use of surgical procedures in private hospitals in Indonesia. Hosp. Pharm. 2019, 54, 323-329. [CrossRef]

21. Bozkurt, F.; Kaya, S.; Gulsun, S.; Tekin, R.; Deveci, Ö.; Dayan, S.; Hoşoglu, S. Assessment of perioperative antimicrobial prophylaxis using ATC/DDD methodology. Int. J. Infect. Dis. 2013, 17, e1212-e1217. [CrossRef] [PubMed]

22. Heuer, A.; Kossick, M.A.; Riley, J.; Hewer, I. Update on Guidelines for Perioperative Antibiotic Selection and Administration from the Surgical Care Improvement Project (SCIP) and American Society of Health-System Pharmacists. AANA J. 2017, 85, 293-299. Available online: https://www.aana.com/docs/default-source/aana-journal-web-documents-1/update-onguidelines-for-perioperative-antibiotic-selection-and-administration-from-the-surgical-care-improvement-project-(scip)-andamerican-society-of-health-system-pharmacists.pdf?sfvrsn=80ad4ab1_4 (accessed on 20 June 2021). [PubMed]

23. Bratzler, D.W.; Dellinger, E.P.; Olsen, K.M.; Perl, T.M.; Auwaerter, P.G.; Bolon, M.K.; Fish, D.N.; Napolitano, L.M.; Sawyer, R.G.; Slain, D.; et al. Clinical practice guidelines for antimicrobial prophylaxis in surgery. Am. J. Health Syst. Pharm. 2013, 70, 195-283. [CrossRef]

24. Billoro, B.B.; Nunemo, M.H.; Gelan, S.E. Evaluation of antimicrobial prophylaxis use and rate of surgical site infection in surgical ward of Wachemo University Nigist Eleni Mohammed Memorial Hospital, Southern Ethiopia: Prospective cohort study. BMC Infect. Dis. 2019, 19, 298. [CrossRef]

25. Crader, M.F.; Varacallo, M. Preoperative Antibiotic Prophylaxis; StatPearls Publishing: Treasure Island, FL, USA, 2020. Available online: https:/ / www.ncbi.nlm.nih.gov/books/NBK442032/ (accessed on 20 June 2021).

26. Ayele, A.A.; Gebresillassie, B.M.; Erku, D.A.; Gebreyohannes, E.A.; Demssie, D.G.; Mersha, A.G.; Tegegn, H.G. Prospective evaluation of ceftriaxone use in medical and emergency wards of Gondar university referral hospital, Ethiopia. Pharmacol. Res. Perspect. 2018, 6, e00383. [CrossRef]

27. Srisung, W.; Teerakanok, J.; Tantrachoti, P.; Karukote, A.; Nugent, K. Surgical prophylaxis with gentamicin and acute kidney injury: A systematic review and meta-analysis. Ann. Transl. Med. 2017, 5, 100. [CrossRef]

28. Branch-Elliman, W.; O’Brien, W.; Strymish, J.; Itani, K.; Wyatt, C.; Gupta, K. Association of Duration and Type of Surgical Prophylaxis with Antimicrobial-Associated Adverse Events. JAMA Surg. 2019, 154, 590-598. [CrossRef]

29. Gachabayov, M.; Senagore, A.J.; Abbas, S.K.; Yelika, S.B.; You, K.; Bergamaschi, R. Perioperative hyperglycemia: An unmet need within a surgical site infection bundle. Tech. Coloproctol. 2018, 22, 201-207. [CrossRef] [PubMed]

30. Chiang, H.Y.; Kamath, A.S.; Pottinger, J.M.; Greenlee, J.D.; Howard, M.A., 3rd; Cavanaugh, J.E.; Herwaldt, L.A. Risk factors and outcomes associated with surgical site infections after craniotomy or craniectomy. J. Neurosurg. 2014, 120, 509-521. [CrossRef] 